Research Article

\title{
Heat Shock Protein 70 (HSP 70) Level in Threatened Abortion
}

\author{
Kadar Heat Shock Protein 70 (HSP 70) pada Abortus Iminens
}

\author{
Bram M Utomo, Eddy Suparman, Linda M Mamengko \\ Department of Obstetrics and Gynecology \\ Faculty of Medicine Universitas Sam Ratulangi/ \\ Prof. dr. RD Kandou Hospital \\ Manado
}

\begin{abstract}
Objective: To determine the level of Heat Shock Protein 70 (HSP 70) in threatened abortion compared with normal pregnancy.

Method: This was a cross-sectional analytic study design conducted to examine the HSP 70 level on 25 subjects of pregnant women with $<20$ weeks of gestation and 30 subjects with threatened abortion. It was held at Obstetrics outpatient clinic Prof. dr. RD Kandou Manado Hospital. The data obtained were analyzed using SPSS software version 22.0 and we did the discussion using the existing literature theory.

Result: The statistical analysis using the Mann-Whitney test showed that there were significant differences of median level of HSP 70 between threatened abortion group and normal pregnancy with less than 20 week of gestation $(\mathrm{p}<0.001)$.

Conclusion: Heat Shock Protein 70 can be a marker to predict the risk of miscarriage in the first trimester of pregnancy.

[Indones J Obstet Gynecol 2016; 4-4: 183-186]

Keywords: HSP 70, pregnancy, threatened abortion
\end{abstract}

\begin{abstract}
Abstrak
Tujuan: Mengetahui perbandingan kadar Heat Shock Protein 70 (HSP 70) pada abortus iminens dibandingkan dengan kehamilan normal.

Metode: Penelitian potong lintang analitik secara komparatif dilakukan dengan memeriksa kadar HSP 70 pada 25 wanita hamil dengan usia kehamilan kurang dari 20 minggu dan 30 subjek dengan abortus iminens. Penelitian ini dilakukan di unit rawat jalan Obstetri RS Prof. dr. RD Kandou Manado. Kami melakukan analisis dengan SPSS versi 22,0 dan diskusi menggunakan teori literatur yang ada.
\end{abstract}

Hasil: Dari analisis statistik dengan menggunakan Uji Mann-Whitney menunjukkan terdapat perbedaan yang bermakna pada kadar HSP 70 antara kelompokaborsi iminens dengan kehamilan normal kurang dari 20 minggu $(p<0,001)$.

Kesimpulan: Heat shock protein 70 dapat menjadi marker untuk memprediksi risiko abortus pada trimester pertama kehamilan.

[Maj Obstet Ginekol Indones 2016; 4-4: 183-186]

Kata kunci: abortus iminens, HSP 70, kehamilan normal

Correspondence: Bram M. Utomo, bramutomo@gmail.com

\section{INTRODUCTION}

Pregnancy is one of frightening events for old couple because many complications often occur on that age. ${ }^{1}$ Threatened abortion as one of complications is a bleeding happening less than 20 weeks of gestation. It can continue for several days or recur and it is usually accompanied by slight pain on the lower abdomen or back pain as like the menstrual period. ${ }^{1}$ Currently, around $15 \%$ of women experience the spontaneous abortion at the conception; however, most of it occur without realizing of it. Meanwhile, 15-20\% cases ended with spontaneous abortion or ectopic pregnancy. ${ }^{2}$ More than $80 \%$ of abortion happen in the first trimester of gestation up to 14-week gestational age. ${ }^{1}$ Apart from that, abortion can also be caused by the imbalance between oxidants and anti-oxidants in uteroplacental; whereas, this balance has an important role in various diseases including abortion.
Cells undergoing environmental stress will encounter the heat shock response (HSR). This response mechanism will involve cell protection called as heat shock protein (HSP) to help an organism dealing with the environmental pressure. ${ }^{3}$ The role of other cellular processes to oxidative stress is called as an ischemic condition. Therefore, member of HSP 70 and co-chaperones play an essential role to sort and control the protein quality through selecting and directing protein to the proteasome. As known, the proteasome has function to disintegrate of damage protein and HSP assists its function.

Heat shock protein is a conservative primary structure of polypeptide which depends on molecular weight. It can be divided into macromolecule (HSP 100 and HSP 90), medium molecule (HSP 70, HSP 60, and HSP 40), and the low molecule (HSP 27 and HSP 10). ${ }^{4}$ Many studies stated that 
HSP 70 influences in variety diseases, such as heart disease, cancer, acute infection, asthma, and pathological pregnancy. Heat shock protein 70 also plays a role in embryogenesis and reproductive cycle. Extracellular protein of HSP 70 is able to induce pro inflammatory immune response (Th1). ${ }^{2}$ Actually, the concentration level of HSP 70 decreases in normal pregnancy. The HSP 70 presents in the peripheral circulation of normal pregnancy. In the meantime, its concentration will decrease as the increase of gestational age. However, it has negative correlation to maternal age. Decreasing level of HSP 70 may lead to the immunological tolerance process to the fetus. Indeed, HSP 70 concentration level is associated with an increased risk of some pregnancy complications. ${ }^{3}$

Intracellular expression of HSP 70 can lead to other obstetrical complications, namely abortion. The HSP 70 in syncytiotrophoblast between 8 and 9 week-gestational age will increase sharply. Meanwhile, the increase of HSP 70 from placenta in the first trimester indicates the miscarriage process. In addition to that, the increase level of HSP 70 on lymphocytes is associated with high risk pregnancy as it signs early onset of pregnancy failure. ${ }^{4} \mathrm{Al}-$ though intracellular HSP 70 has anti-inflammatory effect, extracellular HSP 70 may act as stress signal molecule from non-physiological condition, such as cellular stress or damage, simultaneously with pro inflammatory cytokines both innate or adaptive response. Extracellular HSP 70 binds to surface receptors (CD14, CD36, CD40, CD91, LOX-1, Toll-like receptor 2 and 4) on the Antigen Presenting Cell (APC) and stimulates the proinflammatory cytokines, such as tumor necrosis factor- $\alpha$ (TNF- $\alpha$ ), interleukin (IL-1 $\beta$ and IL-6), chemokines, and nitric oxide production, as well as expression of molecules. The role of cytokines in the inflammatory reaction in whole process is a response to eliminate inflammation. ${ }^{5,6}$

According to the theory, in the first trimester, the placenta will filtrate the maternal blood; thus, the plasma level of HSP 70 will increase in miscarriage pregnancy compared with normal pregnancy. This study aims to determine the level of HSP 70 in threatened abortion compared with normal pregnancy.

\section{METHODS}

This was an analytic observational using cross sectional study design. We held the study by recruiting all pregnant women coming to Obstetrics outpatient clinic at Prof. dr. RD Kandou Manado Hospital from February to April 2016.

The inclusion criteria were women with threatened abortion and normal pregnancy with gestational age less than 20 weeks. The collection of samples was calculated by using a single average formula. After calculating, the minimal samples consisted of 16 threatened abortion women and 16 normal pregnancy with $<20$ weeks of gestation. We excluded all women with molar pregnancy, abnormalities of the uterine, myoma uterine, gestational diabetes mellitus, and pregnancy-induced hypertension.

We examined the level of HSP 70 from subjects' blood through ELISA in Manado Prokita laboratory. We did the analysis using Mann-Whitney test to assess the mean level of HSP 70 on imminent abortion group compared with normal pregnancy. The data obtained were processed using the software program of Statistical Product and Service Solution (SPSS) for Windows version 22.0.

\section{RESULTS}

During the study, we collected 55 subjects of pregnant women. Table 1 showed the characteristics of subjects in this study. Actually, only age and gestational age had normal distribution between threatened abortion and normal pregnancy group ( $p>0.05)$ based on Kolgomorov-Smirnov test. Meanwhile, the other characteristics did not describe normal distribution between the groups.

Table 2 indicated the average level serum of HSP 70 between the groups. In threatened abortion group, the mean, SD, median, and min-max were $1.5,0.3,1.4$, and 1.1-2.2 pg/ml; respectively. Meanwhile, we obtained serum level of HSP 70 in normal pregnancy group with the mean (SD) of $0.3(0.1)$ $\mathrm{pg} / \mathrm{ml}$ and median (min-max) of $0.3(0.2-0.4)$ $\mathrm{pg} / \mathrm{ml}$.

Through using non-parametric statistical test of Mann-Whitney, we got the significant difference $(p<0.001)$ of the median level of HSP 70 between threatened abortion and normal pregnancy groups. Therefore, the concentration of HSP 70 was associated with the occurrence of threatened abortion.

\section{DISCUSSION}

Table 1 described the 55 subjects recruited in this 
Table 1. The Characteristics of Subjects

\begin{tabular}{|c|c|c|c|c|}
\hline \multirow{2}{*}{ Characteristics } & \multicolumn{2}{|c|}{ Theatened Abortion } & \multicolumn{2}{|c|}{ Normal Pregnancy } \\
\hline & $\mathbf{N}$ & $(\%)$ & $\mathbf{N}$ & (\%) \\
\hline \multicolumn{5}{|l|}{ Age (years old)* } \\
\hline $18-23$ & 9 & 30 & 10 & 40 \\
\hline $24-29$ & 11 & 37 & 10 & 40 \\
\hline $30-34$ & 10 & 33 & 4 & 16 \\
\hline $35-39$ & 0 & 0 & 1 & 4 \\
\hline \multicolumn{5}{|l|}{ History of miscarriage } \\
\hline Never & 19 & 63 & 18 & 72 \\
\hline 1 times & 5 & 17 & 5 & 20 \\
\hline$\geq 2$ times & 6 & 20 & 2 & 8 \\
\hline \multicolumn{5}{|l|}{ Education } \\
\hline Elementary & 0 & 0 & 0 & 0 \\
\hline Middle School & 0 & 0 & 1 & 4 \\
\hline High School & 29 & 97 & 24 & 96 \\
\hline Undergraduate & 1 & 3 & 0 & 0 \\
\hline \multicolumn{5}{|l|}{ Smoking } \\
\hline Yes & 1 & 3 & 0 & 0 \\
\hline No & 29 & 97 & 25 & 100 \\
\hline \multicolumn{5}{|l|}{ Gestational age* } \\
\hline 0-6 weeks & 0 & 0 & 0 & 0 \\
\hline 6-12 weeks & 18 & 60 & 12 & 48 \\
\hline $12-20$ weeks & 12 & 40 & 13 & 52 \\
\hline
\end{tabular}

Table 2. The Level Serum of HSP 70

\begin{tabular}{|c|c|c|c|c|c|c|}
\hline \multirow{2}{*}{ Group } & \multirow{2}{*}{$\mathbf{N}$} & \multicolumn{4}{|c|}{ HSP 70 levels (pg/ml) } & \multirow{2}{*}{$\mathbf{p}$} \\
\hline & & Mean & SD & Median & Min-max & \\
\hline Threatened Abortion & 30 & 1.5 & 0.3 & 1.4 & $1.1-2.2$ & $<0.001$ \\
\hline Normal pregnancy & 25 & 0.3 & 0.1 & 0.3 & $0.2-0.4$ & \\
\hline
\end{tabular}

study. Women on 24-29 years old (37\%) were the largest age group for threatened abortion; while, both $18-23$ and 24-29 years old (40\%) were the largest group for normal pregnancy. This study showed there was not association between age and incidence of abortion. Based on study by Baqur AS, et al. in India, they explained that between 24 and 29 years old was the highest group for miscarriage in 2013. ${ }^{7}$ Meanwhile, Tan Hao study in China stated the average group of women undergoing miscarriage was 26 years old in $2007 . .^{8}$ From our study, we got that $63 \%$ of threatened abortion group was never experienced miscarriage and $72 \%$ of normal pregnancy did not have history of mis- carriage. Study by Lena L, et al. in Poland, there was significant relationship between level of HSP 70 and history of recurrent miscarriage on threatened abortion group. ${ }^{9}$ Of educational level, we found the incidence of threatened abortion and normal pregnancy was more common on high school (97\% and 96\%). According to smoking history, we found that almost all subjects never had smoking habit. Study by Hao Tan, et al. in 2007 concluded there was significantly different between smoking habit and abortion in China. ${ }^{8}$ Based on gestational age, we found that the prevalent in 6-12 weeks of gestation $(60 \%)$ and $<20$ weeks of gestation (52\%) for normal preg- 
nancy group. According to the study by Xiangjun Gong, et al. in 2012, they found the most frequent of abortion happened in 6-12-week-gestational age because women felt anxiety and depression in the first trimester. ${ }^{10}$ Meanwhile, Adams, et al. through their study in 2007 stated that miscarriage in the first trimester is usually caused by fetal factors; whereas, $20 \%$ of them are due to fetal abnormalities. ${ }^{11}$

Table 2 indicated that the mean level of HSP 70 in threatened abortion group was 1.51 (SD 0.3) $\mathrm{pg} / \mathrm{ml}$ with a median level of $1.4(1.1-2.2) \mathrm{pg} / \mathrm{ml}$. While, the level of HSP 70 in normal pregnancy group was 0.3 (SD 0.1$) \mathrm{pg} / \mathrm{ml}$ with a median level of $0.3(0.2-0.4) \mathrm{pg} / \mathrm{ml}$. Based on study by Baqur AS, et al. in India, the mean level of HSP 70 in threatened abortion group was from 1.06 to 1.54 $\mathrm{pg} / \mathrm{ml}^{7}$ Our result was not too different from Molvarec, et al. in Hungary, they got the mean level of HSP 70 in normal pregnancy was between 0.27 and $0.39 \mathrm{pg} / \mathrm{ml}^{12}$

The non-parametric statistical test using MannWhitney showed the significant difference of HSP 70 medial level between threatened abortion and normal pregnancy group $(\mathrm{p}<0.001)$. It meant that the HSP 70 had association with abortion. Tan Hao based study in China said that there was positive correlation between HSP 70 and miscarriage. ${ }^{8}$ In contrary to the result, Lena $\mathrm{N}$, et al. in Poland through their study concluded that there was no significant relationship in HSP 70 on both miscarriage and normal pregnancy group. The reason was due to the limitation of smaller sample and they took the sample at 6 weeks' post abortion which might influence the result. ${ }^{9}$

Increased level of HSP 70 in the blood circulation was considered not only as marker of pathological processes, but also having important role in the pathogenesis of abortion. According to Jauniaux, et al. in 2003, they stated that the increased expression of HSP 70 in the placenta at the first trimester caused the miscarriage and it had an essential role to the abortion process. ${ }^{4}$ Meanwhile, according to Hao Tan in 2007, the level of HSP 70 on lymphocytes found to be associated with the risk of pregnancy; however, it was not good as the marker for the first trimester of pregnancy. ${ }^{8}$ Meanwhile, Koga, et al. in 2010 through their study said that HSP 70 could occupy the extracellular toll-like receptor (TLR) inducing proinflammatory cytokines, including IL-1 $\beta$, IL-6 and TNF- $\alpha$. These cytokines would further cause the abortion. ${ }^{13}$

\section{CONCLUSION}

Heat Shock Protein 70 can be a marker to predict the risk of miscarriage in the first trimester of pregnancy.

\section{REFERENCES}

1. Cunningham FG, Leveno KJ, Bloom SL, et al. Williams Obstetrics. Twenty third edition. The McGraw-Hill Companies. 2010: 50 .

2. FU Hartl, MH Hartl. Molecular chaperones in the cytosol: From nascent chain to folded protein: Science 2002; 295: 1852-8.

3. Haslbeck M, Franzmann T, Weinfutner D, et al. Some like it hot: the structure and function of small heat-shock proteins: Na. Struct Mol Biol, 2005; 12: 842.

4. Jauniaux E, Hempstock J, Greenworld N, et al. Trophoblastic. Oxidative Stress in relation to Temporal and Regional Differences in Maternal Placental Blood Flow in Early Normal and Abnormal Pregnancies. Am J Pathol, 2003; 162: 115-25.

5. LH Pearl, C Prodromou. Structure and mechanism of the HSP90 molecular chaperone machinery: Annu. Rev Biochem. 2006; 75: 271.

6. Morimoto RI. Regulation of the heat shock transcriptional response: cross talk between a family of heat shock factors, molecular chaperones, and negative regulators. Genes Dev, 1998; 12: 3788-96.

7. Baqur AS, Kafil A, Raad AA, et al. Heat Shock Protein (Hsp70) Aborted Levels In Women With Toxoplasma gondii Infection. Int J Applied Biol Pharma Technol, 2013; 4: ...-...

8. Tan H, Xu Y, Xu J, et al. Association of Increased levels of heat shock protein 70 in the lymphocyte with high risk of adverse pregnancy outcomes in early pregnancy: a nested case-control study. Cell Stress chaperones, 2007; 12: 230-6.

9. Lena NL, Sypniewska GO, Michalkiewicz J, et al. Evaluation Of Serum Heat Shock Protein 70 Concentration In Women With Recurrent Miscarriages. Folia Medica Copernicana, 2013; 1(2): 58-61.

10. Gong Xiangjun, Jiahu Hao, Fangbiao Tao, et al. 2012. Pregnancy loss and anxiety and depression during subsequent pregnancies: the data from the C-ABC study. Eur J Obstet Gynecol Reprod Biol. 2012; 166: 30-6.

11. Adams KM, Yan Z, Stevens AM, The changing maternal "self" hypothesis: a mechanism for maternal tolerance of the fetus. Placenta, 2007; 28: 378-82.

12. Molvarec A, Rigo J Jr, Nagy B. Serum levels of heat shock protein 70 are Decreased in normal human pregnancy. J Reprod Immunol, 2007; 74: 163-9.

13. Koga K and Mor G. Toll-like receptors at the Maternal-Fetal Interface in normal pregnancy and pregnancy disorders. Am J Reprod Immunol, 2010; 63(6): 587-600. 